ppi $201502 Z U 4645$

Esta publicación científica en formato digital es continuidad de la revista impresa ISSN-Versión Impresa 0798-1406 / ISSN-Versión on line 2542-3185Depósito legal pp $197402 Z$ U34

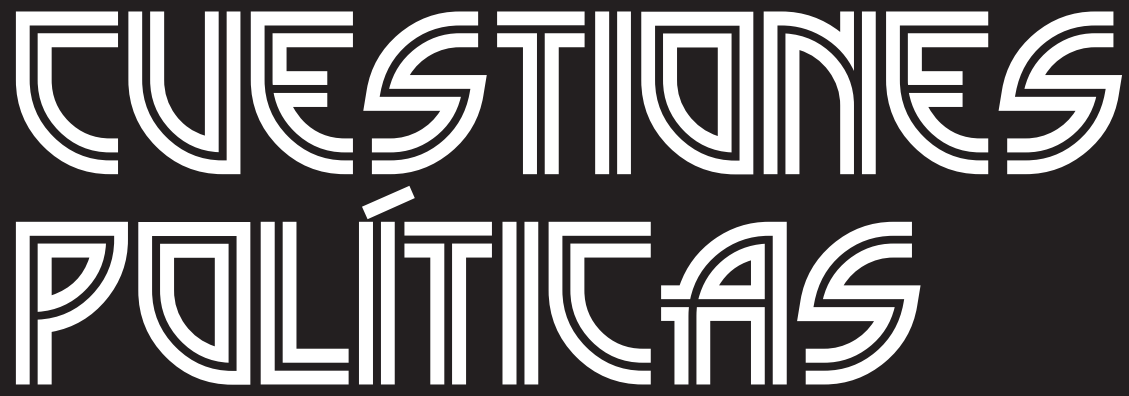

Instituto de Estudios Políticos y Derecho Público "Dr. Humberto J. La Roche" de la Facultad de Ciencias Jurídicas y Políticas de la Universidad del Zulia Maracaibo, Venezuela
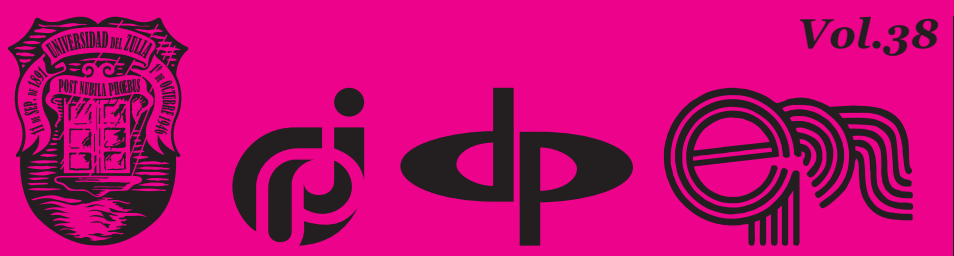

$N^{\circ}$ Especial 1era Parte 2020 


\title{
The Role of Law in Creating Different Policies in Iran's Court of Justice and Punitive Court
}

\author{
DOI: https://doi.org/10.46398/cuestpol.38e.34
}

\section{Mohieddin Mohammadi * Garnik Safariani **}

\begin{abstract}
The principle of respecting the separation of political forces in a society gives the legal system the right to issue orders on people's complaints based on the laws approved by the legislative power. There is no question that laws, like other man-made things, have shortcomings. These decisions include the rupture and even the conflict between two or more articles of the law that provoke the creation of different policies in the court of justice and the punitive court of Iran. With a documentary methodology, this article attempts to study the conflicts between different punitive laws and their effect on the creation of different policies in the courts of Iran. It is concluded that, in many cases, due to different reasons there may be defects in the law or in the interpretation of the law that generate defect, ambiguity, clash between laws and contradiction. The existence of all these failures in different cases will cause conflicts between the judges of the criminal courts and these conflicts are the source of the creation of different legal procedures in the criminal courts and in the short time analyzed.
\end{abstract}

Keywords: Procedures unit; Justice Court; punitive court of Iran; clash of laws; legal hermeneutics.

Ph.D Condidate, Yravan Academy of Legal Sciences, Russia. ORCID: https://orcid.org/oooo-ooo27334-8003. Email: Mohieddin_m@yahoo.com

** Prf. Condidate, Yravan Academy of Legal Sciences. ORCID ID: https://orcid.org/oooo-0002-08433068. Email: law@ysu.am 


\section{El papel de la ley en la creación de diferentes políticas en el tribunal de justicia y tribunal punitivo de Irán}

\section{Resumen}

El principio de respetar la separación de las fuerzas políticas en una sociedad otorga al ordenamiento jurídico el derecho a dictar órdenes sobre las denuncias de las personas con base en las leyes aprobadas por el poder legislativo. No hay duda de que las leyes, al igual que otras cosas hechas por el hombre, tienen deficiencias. Estas decisiones incluyen la ruptura e incluso el conflicto entre dos o varios artículos de la ley que provocan la creación de políticas diferentes en el tribunal de justicia y el tribunal punitivo de Irán. Con una metodología documental en este artículo se intenta estudiar los conflictos entre distintas leyes punitivas y su efecto en la creación de diferentes políticas en los tribunales de Irán. Se concluye que, en muchos casos, debido a diferentes razones puede haber vicios en la ley o en la interpretación de la ley que generan defecto, ambigüedad, choque entre leyes y contradicción. La existencia de todas estas fallas en diferentes casos causará conflictos entre los jueces de los tribunales penales y estos conflictos son la fuente de la creación de diferentes procedimientos legales en los tribunales penales y en el corto tiempo analizado.

Palabras clave: Unidad de procedimientos; tribunal de justicia; tribunal punitivo de Irán; choque de leyes; hermenéutica jurídica.

\section{Introduction}

Law includes a set of bills that have been approved by the members of the parliament. Of course, in some countries special party committees (Sellier, 1999) have the responsibility of approving the laws or in some other countries the king's role has a higher authority in the approval of the laws (Madani et al., 2003). However, the majority of the countries in the world including Iran, the legislation is in the hands of the parliaments; laws that are the only tools of judges in the courts to issue orders. However, in many cases, what the representatives of the parliament vote for and get them approved are totally different from the original draft.

Based on the principal necessity of the separation of the branches, even the legislative branch does not have the right the give an opinion on the matters that have been approved by the parliament other than the exceptional cases which had not much effect on anything. While in some countries such as Austria, the approval of some laws sometimes takes years 
and they will be approved only after lawyers, judges and the law university professors (Katoozian, 2006). The courts' judges will have to take into consideration what has been ratified by the when they are entering their verdicts.

Of course, in recent years because of the lack of knowledge of the law by all the nation's representatives with the skills of writing the law and the principles of giving justice, the duty of approval of the laws is on the parliament's legal commission. Although, this method has its own advantages and disadvantages, the majority of the laws in the country goes back to the previous decades and as far as some of the current countless punitive laws are concerned, cutting off a hand and if the same happens again, the foot and will be determined for the thieves if 16 conditions are they were ratified about 80 years ago and they are currently still followed as valid laws at the time of issuing verdicts by the judges.

Among these cases, we can refer to the single article of conspiracy for taking somebody's possession was ratified in 1929 and or the crime of registering somebody else's possession, the subject of article 109 which is Iran's registration law of 1931 and also the law about the punishment of pouring acid ratified in 1991 which unfortunately after passing even two decades. It is executed as a pilot program and every 5 years it is ratified. Based on this, in the opinion of the writer the main roots deficiencies are in the method of ratification of the laws. Practically, the ratification of legal laws that require expertise, experience and the knowledge in the best possible way should not be done by people who lack the academic ability and the necessary experience. Although, there are problems with putting a limited number of members of the legal commission in charge of the ratification of the laws, it seems that the legislator has decided the only specialized way of ratifying the laws is to allow the representatives of the parliament to do it.

\section{The flaws of the laws}

Although the goal of the editors of the law is to write laws that are practical and flawless in practice, the existence of current flaws in the ratified laws have become the conduit of so many problems for judges when it comes to issuing verdicts thus cause a lot of difficulties for the judges at the time of giving their verdicts.

These flaws are the reasons that in similar cases, different verdicts will be issued by different criminal court that we call them different legal strategies (policies), These flaws are: 
1. Breaking the law.

2. The silence of the law.

3. Conciseness of the law.

4. Contradiction of the law.

Here, we will examine every one of them:

Absence of the law: Dr. Naser Katoozian in his book, "An introduction to the knowledge of the law" has a quotation from Ripper and Boulange that says," the law is defective when it cannot include wisdom and justice in legal activities and legal events.

In cases like this, the judge should utilize the goal of the legislator to find the complementary of that defective verdict.

In this definition the defect of the law includes other issues. In other words, defects such as the silence or the deficiency or the ambiguity or the contradiction of the law comes under the same category. Of course, the breaking of the law can be perceived as the lack of the prediction of the law in a social inappropriate behavior. For example in a case where somebody suffering from AIDS contaminated others on purpose by letting them use his own syringe because of the lack of a law pertaining to that issue in the collection of punitive laws, each of the judges in different courts, had different opinions which is the reason different legal procedures came into existence (Sellier, 1999).

And also about another case in which 4 adult men savagely raped a 4 year old girl in which, unfortunately, there is not a ratified law, Another example is the lack of the law which is considered to be the most important defect in the legislation. The justice department administration has discussed one of the important punitive cases on page 243 of the first volume of a book that was published. As we know in our country and also most of the modern countries in the world, rape has a huge penalty, and the crime of rape is one of that most important punitive crimes. According the Islamic punitive law, conducting a sex act by using force between a man and a woman while it is against the religious decrees, require a death penalty (Madani et al., 2003).

However, in a case where an 8-year-old girl was raped by adult males, no law had been ratified against it. Therefore, two reasons caused these men to go free without punishment for this ugly and inhumane act (Katoozian, 2006). First of all, the terminology "Force" did not apply to this case because the girl was only 8 and the perpetrators of the crime did not need force to commit the crime and secondly:

The legislation has not labeled this a criminal act. The more interesting thing is that even in the credible Islamic religious books, this act has not been 
discussed at all. It was only Shahid Sani while referring to this negligence, attempted to present an opinion for which he has no documentation.

In such cases, where the legislation has not performed its duty and has not ratified a law pertinent to these situations, the judge will face difficult circumstances. Based on article 167 of Iran's constitution: (The judge is required to try to find verdicts for every lawsuit in the books of laws (Sellier, 1999).

Otherwise, he has to refer to Islamic credible sources or the credible ruling (FATVA) to issue a verdict and he cannot be allowed to use silence or deficiency or ignoring or contradiction to refuse issuing a verdict.)

Article 3 of the laws regarding the procedures of justice in the civil affairs ratified in 2000 and article 214 of the laws regarding the procedures of justice in the punitive issue ratified in 1999 has also referred to this subject. Of course, a single article in 1927 under the same topic has required the judges by the legislator to issue verdicts on all lawsuit, otherwise they (judges) would deserve to be punished and even prosecuted and liable for damages.

Article 597 of the Islamic punitive law states: (Any judge who is in charge of taking care of a lawsuit that was filed justly and despite the fact that it was his duty to hear the case and he refuses to do so or delays issuing a verdict, for the first time, he will be excused from the bench for 6 months up to one year and if the same thing happens again, he will be dismissed and will be sentenced to pay damages also (Madani et al., 2003). Here, we have to mention the point that since imposing punishment and damages against judges just because the legislation branch has not done its duties and has not ratified a complete, comprehensive and flawless law in a timely manner and put it at the disposal of the judge, it is in conflict with the fundamental spirit of the justice. Anyway, this issue is one of the most fundamental factors in the creation of different legal policies.

\section{The silence of the law}

Contrary to the basic flaw mentioned above, in many of criminal cases, the legislator has taken measures in identifying the crime and has even issued verdicts for punishment and has also determined certain punishment. However, in the process of identifying the scope of that crime at the time of ratifying the law has not paid enough attention, (For example, none of the laws has any verdict regarding the grace period for the execution of the law overseas and the court has to decide whether the time allowance should be allowed based on the special circumstances of the case or the articles of the law can be used to solve this problem?) 
Now, by studying the criminal cases in Iran's court, different legal procedures resulting from the silence of the law, is considerably interesting. We will refer to some of these examples (Katoozian, 2006): The punishment for the crime of murder in the first degree in Islamic criminal law based on article 612 has been determined to be retribution and if the family of the murder victim gives consent, the criminal will be sentenced to three to ten years imprisonment, In a case in one of the courts in Mazandaran the verdict for the retribution of the murderer was issued and case was dismissed.

But when the retribution was about to happen, the family of the victim declared its consent and based on the law, consent will stop retribution. Now, there is a difference of opinion among the judges in Mazandaran province as whether we cancel again hear the case and issue a new written verdict convicting the murderer to a different kind of punishment which is the same 3-10 years imprisonment.

The legal commission has called this conflict in the legal system "the silence of the law" and has analyzed it in detail and believes that if the legislator gives permission for 2 verdicts to be issued the existence of two different policies in similar cases would have been prevented (Sellier, 1999) and or in another example the judges of the courts in the province of Zanjan because of the lack of fortification position in the limited theft because of the silence of the law in the determination and the issuance of verdict despite the unanimous decision among themselves based on the view of the legal commission, the view of all of them was in conflict with the view of the technical commission (Madani et al., 2003). It is necessary to mention the issue in discussion has been presented in the previous years too and even with the verdicts of Iran's supreme court, the same problem has continued and so far there has been no result yet and the unanimous policy in this case does not exist and for further studies we can refer to the book called the legal common punishment by Dr. Afrasiabi, page 175 and after (Katoozian, 2006).

\section{The summary of the law}

One of the other flaws in writing the law is when the law on the surface does not look defect, but in practice it will be interpreted differently by different judges (Afrasiabi, 1999). For example article 638 of the Islamic punitive law indicates: (Anybody who on purpose and in the public places commits an act that is taboo, in addition to punishment for the action, he/she will be sentenced between 10 days to two months and or up to 74 strokes of whip and if he/she commits an act whose nature does not docs not require punishment, but tamishes the public morality, he will be sentenced to imprisonment from ten days to two months and 1-74 strokes of whip.) 
Unfortunately, Iran's legislator at the time of approving this article of the law ignored a few points: First of all terminologies such as public places and or obvious and or an act of taboo have meanings that are neither clear no standard and practically, anybody can interpret them based on their own interpretations. The same article has an approved amendment that states, (women who go into the public without the legal Hejab, will be imprisoned from ten days to two months and or a monitory punishment in the amount of 50,000 to 500,000 Rials.)

In the amendment also there is no definition of what legal Hejab is without a doubt, in such conditions it is possible a judge to interpret a legal Hejab as wearing a mask and another to consider covering the body just enough and also ne judge might consider "public" as more than 1000 people another judge to merely consider one person as the public place. Without a doubt, such a flaw can have different verdicts for two people who have committed the same crime, Other than the subject of creating different legal policies, it is also possible to interpret the law based on one's taste or to have different interpretations based on one's liking.

\section{Contradiction of the laws}

One of the flaws in the writing of the laws that causes the creation of conflicts in the views of different legal policies in the criminal courts is the contradiction of the laws with one another. In the definition of this flaw, it should be said that: Whenever the legislator approves two or several legal articles about a legal matter in different times or in the shape of one law, as such that the two laws contradict each other, in such a situation, the laws will have conflict with one another and neutralize one another, these laws contradict one another.

Under such conditions, practicing both laws in the same criminal act will be impossible and it will cause creation of different legal procedures in the criminal courts, Dr. Katoozian describes "contradiction of the law" this way... (In the event that the dates of the approval of the two laws are not the same, the new law abolishes the old law... but it happens sometimes that there are laws in a collection of laws that are not possible and it is obvious that it was not the intention of the legislator to implicitly abolish anyone of them because it does not sound right that the first article of the law to compose a law and the 2nd one of the same law to abolish it.)

Cases such as conditions for analysis and the approval of laws and the amount of precision and the effort of the writers and the ratified of the law and more important than anything else the knowledge and the specialty at the awareness of them of the on the collection of ratified laws and... are 
generally those factors that create such conflicts (Sellier, 1999). The conflict on the laws is not pertinent to the common laws and they all the factor for the creation of such mistakes, The conflict of the laws is not pertinent to just common laws and in the constitution of the Islamic Republic also we have noticed the conflicts of the laws against one another. For example (the principle of whether a crime and its punishment is legal or not both in the constitution and also in the common law is faced with ambiguity because between principals of 36 and 167 of the constitution on one hand and article 2 of the Islamic punitive law and article 289 of correcting articles of the law of customary punitive justice of the past, on the other hand are in conflict with each other).

This example is brought up here to point out that the existence of conflict between the laws can happen even in the laws of the constitution and it is interesting to point out that in giving verdicts or votes regarding the unity of the law, we have witnessed that even two verdicts regarding the unity of procedure are in conflict with each other (Madani et al., 2003).

\section{The ambiguity of the law}

In many cases, the existing laws do not have enough power to describe the legislator's intentions and practically they are so ambiguous that judges cannot get a clear and precise understanding of the intention of the legislator and, consequently, they issue verdicts based on their own understanding. For example, in the collection of legal sessions by the justices of the law in Chahar Mahal and Bakhtiari in February and March of 2000, two issues caused conflicts in the verdicts by the judges. The first issue was if in a firstdegree offense, the adult plaintiffs give their consent but the minor ones do not, what will happen to the convict until the minor ones reach the legal age. This problem exists because of the ambiguity in the law. The second issue is whether a woman whose husband is murdered can ask for blood money as part of the whose husband is murdered can ask for blood money as part of the fine imposed on the convict, The majority of the judges said that she could not and the minority said that she could. What is interesting is that the legal commission confirmed the verdict of the minority.

In this brief study, we will see that to reach the legal unified procedure, we need more than anything else the approval of academic laws that are effective; laws that are as much as _ possible unambiguous and there are very few flaws and defects (Katoozian, 2006). Without a doubt, in order to approve better laws, the legislator should have the right qualifications and the method of writing the law should match the importance of the legislation. The last word indicates that the rate of different legal procedures in Iran's criminal courts is directly related to the characteristic of the laws that 
Mohieddin Mohammadi y Garnik Safariani
510 The Role of Law in Creating Different Policies in Iran's Court of Justice and Punitive Court

are legislated by the parliament and are put at the disposal of the judges. The results of study and research indicate that constant legal sessions in different courts show us the existence of serious weaknesses in the method of writing the law and judges try to compensate the flaws and defects of the laws by creating legal procedures.

\section{Conclusions}

Law is one of the basic tools in the courts. In many cases, because of different reasons there might be flaws such as defect, ambiguity, conciseness, and contradiction. The existence of all these flaws in different cases will cause conflicts among judges in the criminal courts and these conflicts were the source of creating different legal procedures in the criminal courts and in this short time, attempts were made to analyze some of these defects.

With special thanks to professor Safarian who guided me in this research.

\section{Acknowlegements:}

The Author is grateful to professor Garnik Safarian to supervision and support this article at Academy of of Legal Sciences in Yerevan, Armenia.

\section{Bibliographic References}

AFRASIABI, Mohammadreza.1999. Common criminallaw. Ferdosi publication, edition. Tehran, Iran.

KATOOZIAN, Naser. 2006. Introduction to the knowledge of the law. Enteshar Corporation. Tehran, Iran.

MADANI, ali; GHAEM, Ziya; BAHRAINIAN, Seyed. 2003. Legal procedure, Avay-e-Noor publication. Tehran, Iran.

SELLIER, Elodie. 1999. Europe's history of criminal law-renee martinez, (Goodarzi, Mohammadreza, trans), Majd publication. Tehran, Iran. 


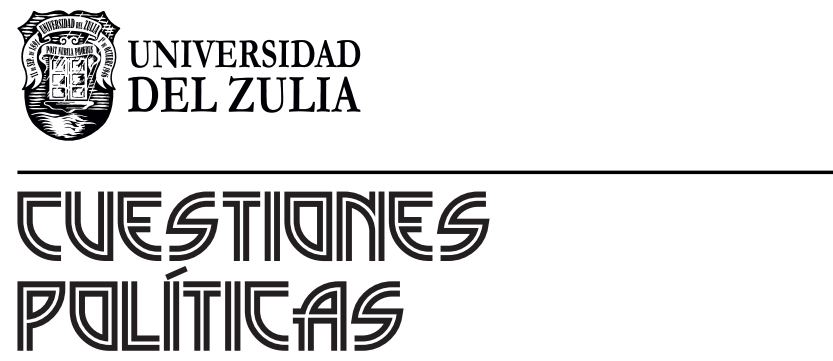

Vol.38 NEspecial

Esta revista fue editada en formato digital y publicada en octubre de 2020, por el Fondo Editorial Serbiluz, Universidad del Zulia. Maracaibo-Venezuela 